WORKING PAPER

THE ETHICS OF CREATIVE ACCOUNTING: SOME SPANISH EVIDENCE

Oriol Amat, John Blake and Ester Oliveras 


\title{
THE ETHICS OF CREATIVE ACCOUNTING: SOME SPANISH EVIDENCE
}

\begin{abstract}
'Creative accounting' involves accountants in making accounting policy choices or manipulating transactions in such a way as to give the impression in the accounts that they prefer. While regarded as unethical by most observers, a defence of creative accounting can be based on the ability of the users of accounts to identify bias in accounting policy choices and make appropriate adjustments.

In this paper we take the example of the Barcelona Football Club where the club management made three key accounting policy choices that presented a favourable position, and a supporters' club presented an alternative report choosing three alternative accounting policies that presented an unfavourable position. We presented each of these financial reports to one of two groups of Spanish bank loan offices, with supporting notes making the impact of the accounting policy choices clear. We found that the more favourable set of accounts was significantly more likely to attract a positive response to a loan request.
\end{abstract}

This result undermines the defence for creative accounting, based on the ability of users to identify manipulation.

Key words: creative accounting, ethics, Spain

Journal of Economic Literature Classifications: M41 


\section{THE ETHICS OF CREATIVE ACCOUNTING: SOME SPANISH EVIDENCE}

\section{Introduction}

Accountants can use their knowledge of accounting rules to manipulate the figures reported in the accounts of a business. This process has come to be commonly referred to as 'creative accounting', particularly in the UK, (see for example Griffiths 1986, Jameson 1988, Naser 1993), or also, particularly in the USA, as 'earnings management' (see for example Merchant and Rockness 1994, Fischer \& Rosenzweig 1995). The former term has been taken up in Spain, as 'contabilidad creativa' (see for example Amat \& Blake 1996, Lainez \& Callao 1999).

In this paper we review the literature on the nature of 'creative accounting' and consider the evidence on the experience of creative accounting in Spain. We then discuss the ethics of creative accounting, identifying as a key element in the debate the issue as to whether creative accounting affects the decisions made by users of accounts. Finally, we consider an example in Spain of a dispute as to the appropriate choice of accounting policies in the case of the Barcelona Football Club (FCB), and report on the response of Spanish bank loan officers to the accounts of a loan applicant using the most favourable accounting policies in the FCB case, and compare these to the response of Spanish bank loan officers to a loan applicant using the least favourable accounting policies in the FCB case. 


\section{The nature of creative accounting}

Four books in the UK, each written from a different perspective, have considered the creative accounting issue:

Griffiths (1986) writing from the perspective of a business journalist, observes:

"Every company in the country is fiddling its profits. Every set of published accounts is based on books which have been gently cooked or completely roasted. The figures which are fed twice a year to the investing public have all been changed in order to protect the guilty. It is the biggest con trick since the Trojan horse ... In fact this deception is all in perfectly good taste. It is totally legitimate. It is creative accounting". (p1)

Jameson (1988) writing from the perspective of the accountant, argues:

"The accounting process consists of dealing with many matters of judgement and of resolving conflicts between competing approaches to the presentation of the results of financial events and transactions ( $p 7$ ) ... this flexibility provides opportunities for manipulation, deceit and misrepresentation. These activities practised by the less scrupulous elements of the accounting profession - have come to be known as 'creative accounting' (p8).

Smith (1992) reports on his experience as an investment analyst:

"We felt that much of the apparent growth in profiles which had occurred in the 1980 's was the result of accounting sleight of hand rather than genuine economic growth, and we set out to expose the main techniques involved, and to give live examples of companies using those techniques". (p4)

Naser (1993) presenting an academic's view, offers a definition:

"Creative accounting is the transformation of financial accounting figures from what they actually are to what preparers desire by taking advantage of the existing rules and/or ignoring some or all of them" (p. 2) 
Some common themes run through these books:

Creative accounting involves 'fiddling' and 'figures which have been changed' (Griffiths) to achieve 'misrepresentation' (Jameson) by 'sleight of hand' (Smith) to transform figures from 'what they actually are' (Naser). Explicit in Naser, and implicitly in the other three accounts, is that there is some underlying objective truth and that creative accounting departs from this. Creative accounting is seen as widespread in the UK. Naser perceives the accounting system in Anglo-Saxon countries as particularly prone to such manipulation because of the freedom of choice it permits, observing "The freedom of choice provided by Anglo-Saxon accounting system could be abused ..." (p.1). Similarly Waller (1990), addressing the problem of 'creative accounting' in the UK, advocates a move to the more legal and prescriptive continental tradition as a solution. Finally all four authors perceive creative accounting as a disreputable practice, using terms such as 'fiddling', 'deceit' and 'taking advantage'.

The relative extent of creative accounting in the UK and in a continental European country, Spain, is considered in the following section. The ethical debate over creative accounting is then reviewed. We turn now, therefore, to the first question, being whether there is some underlying objective accounting truth from which 'creative accounting' can be deemed to depart.

Blake et al (1998) argue that there are four ways in which creative accounting may arise. Firstly by the exercise of choice between permitted alternative accounting policies. An example would be in choosing whether to write off or capitalise research and development costs. Secondly by applying bias in the making of accounting estimates. An example would be in the estimation of asset life for depreciation purposes. Thirdly by structuring transactions in such a way as to manipulate the accounts. For example, in a sale and leaseback arrangement the sale proceeds of an asset might be artificially depressed or boosted with an equivalent adjustment to related rental payments. Finally by timing genuine transactions so as to manipulate the accounts. For example, if an investment with a historic cost of $£ 1$ million has a market value of $£ 3$ million, then managers can time realisation to boost profits in the year of their choice. 
The first two of these might be termed 'accounting manipulation'. The problem of defining an accounting policy choice as 'manipulative', and therefore 'creative' is that where accounting regulation permits such choice then this is likely to reflect legitimate debate over the issue concerned. As an example, Robson (1994) points out that in the mid 1970's the UK Sandilands report on inflation accounting identified twenty possible combinations of net asset and capital maintenance that could define profit. Thus it is not the individual policy choice in itself that constitutes 'manipulation' but the intention behind it. One way to identify a tendency towards a 'creative' bias in company accounts is to consider the impact of its overall selection of accounting policies. Thus, Smith (1992) identifies twelve accounting policy choices each of which tends to put company performance in a favourable light. He observes:

"inclusion in the list of any particular technique does not automatically mean that the company is indulging in creative accounting" ( $p 184)$

However, where a number of such accounting approaches arise in one company's accounts then the suspicion of manipulation grows.

\section{The Spanish context}

Spain only acquired a set of accounting rules for all companies with the Plan General de Contabilidad (PGC - General Accounting Plan) of 1973. In the period 1988 - 1990, a series of laws introduced an audit requirement, prescribed consolidated accounts, and culminated in full implementation of the EU directives on accounting and auditing in the PGC of 1990. Concerns that, within this framework, Spanish companies are engaging in creative accounting have been expressed by a range of observers (see Giner 1992, Rojo 1993, Rodriquez Molinuevo 1996, Amat et al 1997, Rodriquez-Vilarino 1998, Lainez \& Callao 1999).

We have seen above that some observers in the UK have perceived the Anglo-Saxon tradition of flexibility in accounting policy choice as giving rise to more scope for creative accounting than the continental European tradition. Amat and Blake (1996) report on a survey of Spanish auditors' views on creative accounting, and compare this with a similar survey in the UK reported by Naser (1993). Table 1 compares two key 
responses. It is striking that in both countries both the importance and the legitimacy of creative accounting appear to be viewed similarly.

Table 1. Summary of results on auditor's attitudes towards creative accounting

\begin{tabular}{|llc|}
\hline Question & \multicolumn{2}{c|}{ Agree or Strongly Agree } \\
& Spain & United Kingdom \\
$\begin{array}{l}\text { Do you consider the use of creative } \\
\text { accounting to be a serious problem? }\end{array}$ & $65.5 \%$ & $64.3 \%$ \\
$\begin{array}{l}\text { Do you consider that the use of creative } \\
\text { accounting is a legitimate business tool? }\end{array}$ & $31 \%$ & $35.7 \%$ \\
\hline
\end{tabular}

\section{The ethics of creative accounting}

We have seen above that all four UK commentators saw creative accounting as inherently disreputable. Similarly in the USA, the then senior partner in Price Waterhouse, termed such an approach 'fraudulent' (Conner 1986, p78). In Australia, Leung and Cooper (1995) report that in a survey of 1500 accountants the three most frequently cited ethical problems were as shown in table 2 . It is striking that creative accounting ranks above tax evasion as an issue.

Table 2: Three most frequently cited ethical problems

\begin{tabular}{|lc|}
\hline & $\%$ of respondents \\
Conflict of interest & $51.9 \%$ \\
Client proposal to manipulate accounts & $50.1 \%$ \\
Client proposal for tax evasion & $46.8 \%$ \\
\hline
\end{tabular}

Source: Leung and Cooper (1995)

Two surveys of attitudes to creative accounting in the USA both highlighted contrasting attitudes to 'accounting manipulation' and 'transaction manipulation'. Fischer and Rosenzeig (1995) found that accounting and MBA students were more critical than accounting practitioners of manipulated transactions, whereas accounting practitioners were more critical than students of abuse of accounting rules. Similarly Merchant and Rockness (1994) found that, when presented with scenarios of creative accounting, 
accountants were more critical of accounting manipulation than transaction manipulation. Merchant and Rockness also found a difference in accountants' attitudes to creative accounting depending on the motivation of management. Creative accounting based on explicitly motives of self interest attracted more disapproval than where the motivation was to promote the company.

A contrasting view is put forward by Revsine (1991). He offers a discussion of the 'selective financial misrepresentation hypothesis' which can be seen as offering some defence for the practice of 'creative accounting', at lease in the private sector, drawing heavily on the literature on agency theory and positive accounting theory. He considers the problem in relation to both managers and shareholders and argues that each can draw benefits from 'loose' accounting standards that provide managers with latitude in timing the reporting of income.

Revsine discusses the benefits to managers in being able to manipulate income between years so as to maximise their bonus entitlements, as discussed above. He argues that:

'It is reasonable to presume that those who negotiate managers' employment contracts anticipate such opportunistic behaviour and reduce the compensation package accordingly ... since they (managers) have already been 'charged' for the opportunistic actions they must now engage in them in order to achieve the benefits they 'paid' for."(p. 18)

Shareholders also benefit from the fact that managers can manipulate reported earnings to 'smooth' income since this may decrease the apparent volatility of earnings and so increase the value of their shares. Other management action, such as avoiding default on loan agreements, can also benefit shareholders.

At the heart of Revsine's analysis are the implicit views that:

- the prime role of accounting is as a mechanism for monitoring contracts between managers and other groups providing finance;

- market mechanisms will operate efficiently, identifying the prospect of accounting manipulation and reflecting this appropriately in pricing and contracting decisions. 
While the second point is supported in relation to shareholders by the literature on market efficiency (for summaries of this see for example Watts \& Zimmerman, 1986) there is little research on whether other user groups may be misled by accounting manipulation. There has been research on the response of bank loan officers to accounts where difference accounting policies in respect of one specific area of choice have been presented. These cover two area:

1. The choice between treating a long term lease agreement in accordance with its commercial substance, so that the leased asset is shown as an asset and the related obligation to make lease payments is shown as a liability, or showing the transaction in accordance with its legal form, so that only the rental payments are disclosed as an expense. Studies in the USA (Abdel-Khalik et al 1981), Singapore (Wilkins and Zimmer 1983), and Spain (Blake et al 1995), all indicate that the former accounting policy choice, which portrays a company as having higher borrowings, leads to that company being viewed less favourably by bank loan officers.

2. The choice between treating development costs and an asset, to be amortised against future income from the related project, and as an expense in the year they are incurred. In the USA, McGee (1984) reports that bank loan officers clearly took a more favourable view of company accounts where the first policy was adopted.

Thus we have evidence from four studies in three countries that a key user group are influenced in their assessment of financial statements by the accounting policy choices made in one specific area, and therefore are vulnerable to having their decisions affected by the accounting policy choice made in company accounts. In this study we seek to extend this insight by considering whether a collection of accounting policy choices which together may bias an entity's reported performance in a favourable, or alternatively an unfavourable, direction, have a similar impact on the decision making of bank loan officers. To construct a realistic case to test this issue we have taken the first instance in Spain where there has been a public debate over the collective impact of a collection of accounting policy choices, the case of the Barcelona Football Club. 


\section{The Barcelona Football Club Case}

In July 1998, the annual accounts of the Barcelona Football Club (FCB) were published, with a clean audit report from the joint auditors, KPMG and Price Waterhouse Coopers. In December 1998, a supporters club, Elefant Blau (EB), commissioned an alternative financial report from two local auditing firms and a local consulting firm. The FCB accounts showed a net profit of 492 million pesetas, compared with the EB version which showed a net loss of 3720 million pesetas. The difference was attributable to three differences in accounting policies:

1. The accounting treatment of costs of extending or renewing player contracts. The FCB accounts, for the first time, treated these as assets to be capitalised and then amortised over future years. The EB version wrote these costs off immediately in the profit and loss account, as had been done in the FCB accounts in previous years.

2. FCB was subject to a tax penalty of 3512 million pesetas. Having taken advice that the club was likely to be relieved of this penalty on appeal, the club made no provision for this liability in the accounts. EB's version made such a provision.

3. FCB had treated 3229 million pesetas of transfer fees received as ordinary income. EB also treated this as income, but as an extraordinary item.

Thus in each case where a permitted accounting policy choice could be made FCB chose the most favourable and EB the least favourable option. We do not attempt here to evaluate which choice had more validity in each case. It could be argued that both parties, in consistently showing a bias in one direction, were equally prone to 'creative accounting'.

Two summarised versions of the FCB accounts were prepared, one on the basis on the FCB chosen accounting policies and one on the basis of the EB chosen accounting policies. Full disclosure was made for each of the three accounting policy choices. A questionnaire attached to the accounts asked:

1. Would the respondent give a short term loan of 200 million pesetas to the enterprise? 
2. If so, at what interest rate?

3. Would the respondent give a five year loan of 400 million pesetas to the enterprise?

4. If so, at what interest rate?

The questionnaire was given to Spanish bank loan officers attending management development courses at three business schools in Barcelona, Zaragoza and Madrid. In each case the FCB version was given to half the class and the EB version to the other half. Each version was given out in blocks so as to eliminate the risk of participants seeing both versions, and so being influenced in their choice. Each population has been analysed for gender, age and length of experience, and has an equivalent spread of these factors.

Our hypothesis is that if creative accounting does influence the judgement of bank loan officers then in each case this will be reflected in the more favourable assessment of the FCB version of the accounts than of the EB version. The results, as summarised in table 3, support the hypothesis. In relation to the short term loan, the results is significant at a confidence level of $95 \%$, and in the case of the long term loan at a confidence level of $99 \%$. 
Table 3: Summary of results

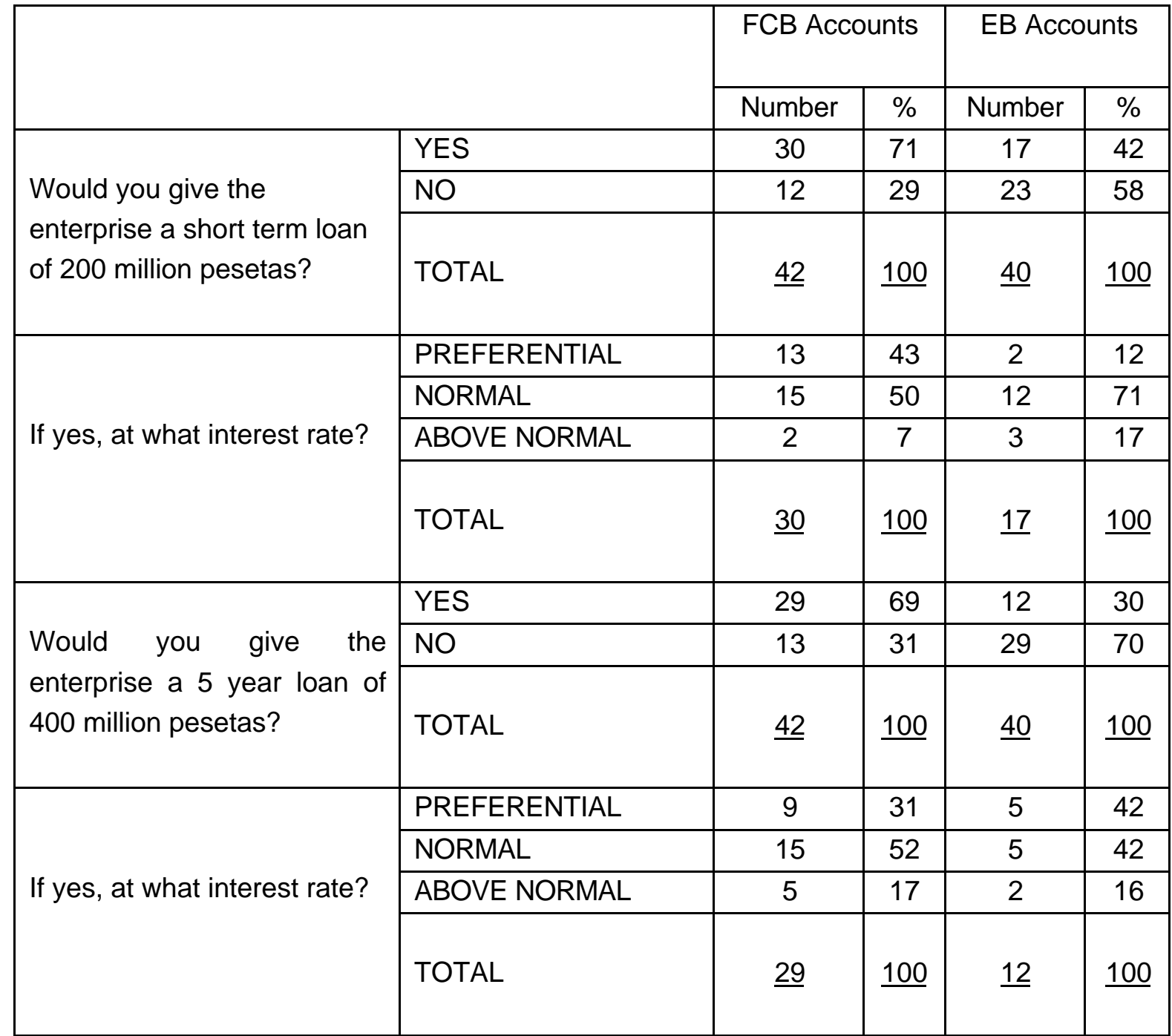

\section{Conclusion}

We have seen that 'creative accounting' has been seen as primarily an 'Anglo American' problem, but has caused growing concern in Spain, and is widely perceived as ethically undesirable, but has been defended on the grounds that users will both expect it to arise and be capable of identifying it.

We have taken a Spanish case where, on a combination of three accounting policy choices, a strongly contrasting view can emerge between a favourable and an unfavourable view of an entity's performance. Presenting these two different views to Spanish bank loan officers we have found that in loan making decisions a choice of favourable accounting policies does lead to a more favourable assessment of an entity's 
financial capacity, even though the alternative unfavourable view is clearly identifiable from brief notes to the accounts. Our findings are consistent with earlier research in other countries which indicates that accounting policy choice in one individual area of accounting policy choice can bias the decision making of bank loan officers.

Our study, therefore, adds to the evidence that for one key user group, at least, bias in accounting policy choice does have an impact on user decision. We would argue that this offers some challenge to Revsine's defence of 'earnings management'.

\section{References}

Abdel-Khalik AR (1981), "The economic effects on lessees of FASB Statement No. 13: Accounting for leases", Stanford Connecticut, Financial Accounting Standards Board.

Amat O and Blake J (1996), Contabilidad Creativa, Barcelona: Gestión 2000.

Amat O and Moya S and Blake J (1997), "La contabilidad creativa", Partida Doble, June, PP 24-32.

Blake J, Amat O and Clarke J (1995), "Managing the economic impact of accounting regulation: the Spanish case", European Business Review, Vol 95, No. 6, pp 26-34.

Blake J, Amat O and Dowds J (1998), "The ethics of creative accounting", in Gowthorpe C and Blake J, "Ethical issues in accounting", London: Routledge, pp 24-40.

Conner J E (1986), 'Enhancing public confidence in the accounting profession', Journal of Accountancy, July: 76-83.

Fischer M and Rosenzweig K (1995), 'Attitudes of students and accounting practitioners concerning the ethical acceptability of earnings management', Journal of Business Ethics, 14: 433-44.

Giner B (1992), "Un vistazo a la contabilidad creativa”, Partida Doble, March, pp 4-12.

Griffiths I (1986), "Creative Accounting", London: Sidgwick \& Jackson. 
Jameson M (1988), Practical Guide to Creative Accounting, London: Kogan Page.

Lainez J and Callao S (1999), "Contabilidad creativa", Madrid: Civitas Ediciones.

Leung P and Cooper BJ (1995), 'Ethical dilemmas in accountancy practice', Australian Accountant, May: 28-33.

McGee RW (1984), "Software accounting bank lending decisions and stock prices", Management Accounting, July, pp 20-23.

Merchant KA and Rockness J (1994), 'The ethics of managing earnings: an empirical investigation', Journal of Accounting and Public Policy, 13: 79-94.

Naser K (1993), Creative financial accounting: its nature and use, Hemel Hempstead: Prentice Hall.

Revsine L (1991), "The selective financial misrepresentation hypothesis", Accounting Horizons, December, pp 16-27.

Robson K (1994), "The discourse of inflation accounting, on the interrelationships between economic theory and debates on inflation accounting", European Accounting Review, Vol 3, No. 2, pp 195-214. 
Rodriguez Molinuevo J (1996), "Una aproximacion critica a la contabilidad creativa" in "Ensayos sobre contabilidad y economia", Madrid: Instituto de Contabilidad y Auditoria de Cuentas.

Rodriquez Vilarino M (1998), "Imagen fiel versus contabilidad creativa", Técnica Contable, July, pp 547-550.

Rojo LA (1993), "Tendencias de contabilidad y contabilidad creativa", Boletin, AECA, No. 36, pp 4-7.

Smith T (1992), "Accounting for growth”, London: Century Business.

Waller D (1990), "Time to get rid of true and fair view?", Accountants Magazine, December, p53.

Watts RL and Zimmerman JL (1986), "Positive accounting theory", Englewood Cliffs, New Jersey: Prentice Hall.

Wilkins T and Zimmer I (1983), "The effects of alternative methods of accounting for leases - an experimental study", Abacus, June, pp 64-75. 